\title{
Pengaruh Efektivitas Penerapan Sistem Informasi Akuntansi, Kesesuaian Tugas dan Kenyamanan Fisik Pada Kinerja Karyawan \\ LPD
}

\author{
Ni Putu Widiantari' \\ Fakultas Ekonomi dan Bisnis \\ Universitas Udayana, Indonesia. \\ Email: widyahariguna@gmail.com
}

\author{
Ni Luh Sari Widhiyani ${ }^{2}$ \\ Fakultas Ekonomi dan Bisnis \\ Universitas Udayana, Indonesia.
}

\begin{abstract}
ABSTRAK
Penelitian ini memiliki tujuan untuk memperoleh bukti mengenai faktor yang berpengaruh pada kinerja karyawan di Lembaga Perkreditan Desa Kabupaten Badung, yang meliputi efektivitas penerapan sistem informasi akuntansi, kesesuaian tugas dengan teknologi informasi, dan kenyamanan fisik. Penelitian dilakukan di LPD Kabupaten Badung dengan populasi berjumlah 366 orang. Sampel ditentukan dengan menggunakan rumus solvin yaitu 191 orang. Yang dijadikan responden pada penelitian ini adalah karyawan yang terlibat langsung dengan teknologi informasi, yaitu ketua LPD, bendahara, dan tata usaha. Metode regresi linear berganda merupakan teknik analisis data yang digunakan dalam penelitian ini. Penelitian memperoleh hasil bahwa efektivitas penerapan teknologi informasi memiliki pengaruh positif pada kinerja karyawan. Begitupula kesesuaian tugas dengan teknologi informasi berpengaruh positif pada kinerja karyawan. Kenyamanan fisik juga menunjukkan pengaruh positif terhadap kinerja karyawan.
\end{abstract}

Kata Kunci : Kinerja; Efektivitas; Kesesuaian Tugas; Kenyamanan.

\section{Effect of Effectiveness of Application of Accounting Information Systems, Task Suitability and Physical Comfort on Employee Performance LPD}

\begin{abstract}
This study aims to obtain evidence regarding the factors that influence the performance of employees in LPD in Badung Regency, which include the effectiveness of the application of accounting information systems, suitability of tasks with information technology, and physical comfort. The study was conducted in the LPD of Badung Regency with a population of 366 people. The sample is determined using a solvin formula which is 191 people. The respondents used in this study were employees who were directly involved with information technology, namely the chairman of the LPD, treasurer, and administration. Multiple linear regression method is a data analysis technique used in this study. The research obtained results that the effectiveness of the application of information technology has a positive influence on employee performance. The suitability of the task with information technology and Physical comfort also shows a positive influence on employee performance.
\end{abstract}

$\begin{array}{ll}\text { Keywords: } & \text { Performance; Effectiveness; Tasks Suitability; } \\ \text { Comfortness. } & \end{array}$

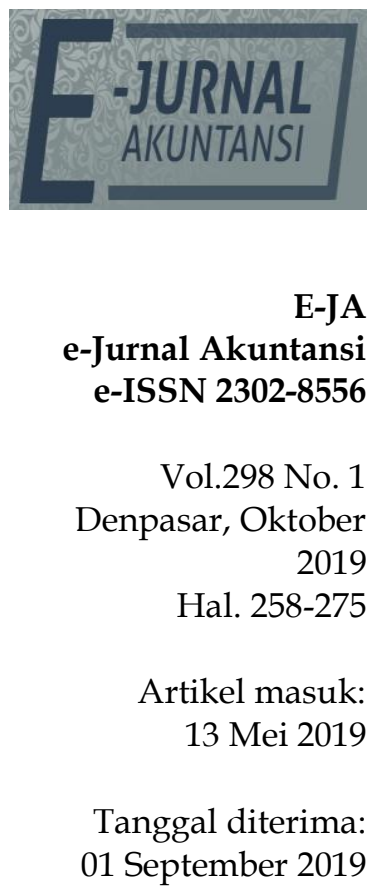

01 September 2019 


\section{PENDAHULUAN}

Lembaga Perkreditan Desa (LPD) merupakan lembaga milik desa pakraman yang memiliki tujuan untuk mengelola keuangan masyarakat pedesaan. Lembaga ini cukup sukses di Provinsi Bali sebagai lembaga keuangan yang dapat membantu dan mendorong ekonomi desa, hal inilah yang membuat LPD dituntut untuk meningkatkan kinerjanya baik dari segi sumber daya manusia maupun dari teknologi yang dipergunakan untuk menunjang operasionalnya. Karyawan sebagai salah satu modal LPD diharuskan untuk menunjukkan kinerja terbaik kepada masyarakat, untuk meningkatkan minat mereka (Veriana \& Budiartha, 2016). Dilihat dari aset yang dimiliki, LPD di Bali terus mengalami peningkatan. Hal ini menunjukkan bahwa LPD memiliki andil yang cukup besar dalam ekonomi masyarakat Bali. selain sumber daya manusia, teknologi menjadi hal yang patut untuk diperhatikan.

Prioritas utama LPD adalah melakukan pengelolaan uang masyarakat secara tertib dan mampu menghasilkan keuntungan dari itu. Semakin berkembang LPD maka transaksinya akan semakin kompleks. Kompleksitas ini menuntut LPD untuk menggunakan metode yang efektif dan efisien dalam melakukan pengelolaan keuangan. Perkembangan teknologi menjadi salah satu cara efektif untuk diterapkan dalam LPD dalam menangani kompleksitas transaksi yang ada, yaitu mulai menerapkan teknologi yang semakin berkembang.

Sistem informasi yang dikembangkan dalam organisasi dan lembagalembaga pada dasarnya memiliki tujuan untuk mengolah informasi secara cepat, dan akurat serta tidak membuat kebingungan (Indralesmana \& Suaryana, 2014). Efektivitas sistem yang digunakan dapat dilihat dari manfaat yang diberikan oleh sistem tersebut, apakah memberikan manfaat bagi penggunanya ataupun tidak. Karyawan suatu organisasi dituntut untuk dapat memanfaatkan sistem dengan sebaiknya yang sangat menunjang kualitas hasil kerja mereka, sehingga dibutuhkanlah pemahaman dan pengetahuan serta keterampilan yang cukup dalam mempergunakan sistem informasi yang dipergunakan dalam lembaga. memberikan peluang bagi bisnis dengan tujuan demi melaksanakan kegiatan seefektif dan se-efisien mungkin, sehingga dengan demikian perusahaan akan memiliki kelebihan yang tidak dimiliki perusahaan lain (Edison, et al., 2012).

Meningkatnya ketergantungan organisasi pada Sistem Informasi Akuntansi untuk memenuhi misi mereka di era informasi ini menuntut pendekatan proaktif dan strategis untuk manajemen kualitas data. Data dan Informasi adalah bahan dasar dari semua kegiatan setiap usaha manusia. Mereka mendorong proses perolehan material, penagihan, menyiapkan estimasi dan anggaran. informasi akuntansi hanya sebagus data dasar yang disimpannya dan informasi yang disajikannya. Informasi akuntansi yang disampaikan secara andal dan tepat waktu sangat penting untuk manajemen setiap organisasi. Memang perencanaan dan pemberian layanan yang efektif sangat bergantung pada informasi akuntansi. Sistem Informasi Akuntansi telah bergantung pada pena dan kertas di masa lalu tetapi Teknologi Informasi tidak diragukan telah mengubah lingkungan kerja seorang akuntan. Dasar Sistem Informasi Akuntansi adalah menyediakan informasi yang tersedia dan dapat diakses untuk mendukung keputusan dan meningkatkan layanan dan operasi. Informasi yang 
dapat digunakan dengan cara ini harus akurat, dapat diandalkan, dan konsisten untuk membuat keputusan bisnis yang cerdas dan efektif berdasarkan fakta. Jika tidak demikian, Sistem Informasi Akuntansi menjadi tidak berguna dan hanya pemborosan sumber daya.

Sistem SIA yang efektif memungkinkan organisasi untuk meningkatkan efektivitas dan efisiensi operasional. Sistem informasi akuntansi meningkatkan kualitas kerja, memungkinkan organisasi untuk menyelesaikan masalah yang kompleks, dan membantu dalam integrasi semua departemen. Ini juga memungkinkan organisasi untuk bersaing secara menguntungkan di lingkungan pasar. Selanjutnya, SIA memfasilitasi pertukaran data antara berbagai program; ini membantu dalam menyelaraskan berbagai subsistem dalam organisasi, dan secara keseluruhan menyediakan sistem pengiriman layanan yang efisien dan efektif (Zare, 2012). Selain itu, Zare, (2012) menemukan bahwa SIA membantu memberikan informasi keuangan yang tepat waktu yang memfasilitasi keputusan mengenai peminjaman dana dan membuat kebijakan keuangan. Sistem informasi akuntansi memberikan gambaran yang akurat tentang posisi keuangan dan pasar organisasi. Ini juga memungkinkan organisasi untuk membuat perbandingan antara posisi keuangan saat ini dan sebelumnya untuk evaluasi kinerja. Selain memungkinkan organisasi untuk mengevaluasi kekuatan dan kelemahan internal melalui laporan keuangan, SIA yang efektif memfasilitasi komunikasi, perencanaan, dan pengambilan keputusan dalam organisasi.

Pada penelitian ini peneliti mengambil lokasi di Kabupaten Badung, berdasarkan beberapa pertimbangan, seperti LPD di Kabupaten Badung adalah lembaga keuangan yang mampu meningkatkan kesejahteraan ekonomi masyarakat desa, penggunaan teknologi yang sangat baik diterapkan oleh masing-masing LPD. Pada tahun 2017 jumlah LPD yang tersebar di enam kecamatan di Kabupaten Badung tercatat oleh LPLPD sebanyak 122 LPD. Dari jumlah tersebut, diketahui sebanyak 85 LPD menggunakan teknologi informasi, dimana data ini diperoleh dari LPLPD Badung pada tahun 2019.

Lembaga Perkreditan Desa di Kabupaten Badung menjadi LPD dengan asset tertinggi diantara kabupaten lainnya di Provinsi Bali, yang rinciannya dapat dilihat pada tabel 1 .

Tabel 1. Perbandingan Aset LPD Per Kabupaten

\begin{tabular}{ccc}
\hline No. & Nama Kabupaten & Jumlah Asset (Rp) \\
\hline 1. & Badung & 5,9 triliun \\
2. & Gianyar & 3,6 triliun \\
3. & Tabanan & 1,4 triliun \\
4. & Karangasem & 1,2 triliun \\
5. & Buleleng & 1,9 triliun \\
6. & Klungkung & 743 miliar \\
7. & Bangli & 854 miliar \\
8. & Jembrana & 539 miliar \\
9. & Denpasar & 1,9 triliun \\
\hline
\end{tabular}

Sumber: Data Penelitian, 2019

Data pada tabel 1. menunjukkan bahwa jumlah asset yang besar berarti volume transaksi juga besar, dan sangat tidak memungkinkan apabila SIA tidak 
dipergunakan dalam transaksi besar seperti itu. Oleh karena itu, tidak heran apabila LPD di Kabupaten Badung menerapkan SIA secara serentak, dan memberikan pelatihan secara berkala kepada karyawannya demi mencapai kinerja yang maksimal.

Teknologi yang canggih tentunya akan semakin bermanfaat apabila penggunanya juga memiliki pemahaman dan keterampilan yang sesuai dengan teknologi tersebut. Kecanggihan teknologi yang tidak dibarengi dengan kecakapan si pemakai juga tidak akan membuahkan hasil kinerja sesuai harapan. LPD yang dulunya masih menggunakan sistem manual, dengan semakin berkembangnya jaman juga telah beralih menggunakan sistem dengan berbasis komputer. Beberapa system berbasis komputer yang telah diadopsi oleh LPD seperti Gio Shop, Acosys, Fina dan Abipro yang justru telah membantu operasional LPD sejak 2015 silam. Meskipun Kabupaten Badung tercatat sebagai kabupaten dengan penggunaan SIA yang tinggi, namun tidak menutup kemungkinan untuk terjadinya ketimpangan dari segi penggunaannya. Benar saja, bahwa LPD dengan penggunaan teknologi hanya berfokus pada LPD di Kecamatan Kuta dan Mengwi saja, masih ada beberapa LPD seperti yang terletak di Badung Utara yaitu beberapa di Kecamatan Petang dan Abiansemal yang masih minim penggunaan teknologinya. Hal ini tentu saja mempengaruhi kinerja LPD secara keseluruhan, seperti yang dikatakan sebelumnya bahwa volume transaksi dan transaksi yang kompleks akan jauh lebih efektif jika dikerjakan dengan bantuan teknologi.

Pihak yang memiliki kepentingan terhadap organisasi berhak untuk mengetahui kinerja para karyawan sebagai salah satu tolok ukur tercapai atau tidaknya tujuan organisasi (Ochoti, et al., 2012). Kinerja karyawan dan organisasi dapat dicapai dengan memanfaatkan SIA, sesuai atau tidaknya tugas yang diberikan, dan kenyamanan yang diperoleh karyawan di lembaga atau organisasi yang bersangkutan. Teori TAM atau yang merupakan kependekan dari Technology Acceptance Model merupakan teori yang menyatakan bahwa apabila akan menerapkan suatu sistem ataupun teknologi baru dalam organisasi, maka terlebih dahulu harus dipastikan bagaimana reaksi yang akan diterima ketika teknologi tersebut telah digunakan, dimana teori ini dirintis pertama kali oleh Davis (1989). Model ini mengacu pada dua pokok utama, yakni adanya kebermanfaatan dan memiliki kemudahan. Karyawan yang meyakini bahwa teknologi yang diterapkan mampu memberikan manfaat dan mudah digunakan akan dapat mengadopsi teknologi tersebut dengan baik.

Apabila sistem yang digunakan dalam organisasi sesuai dengan yang dibutuhkan dan sesuai dengan pekerjaan yang akan dilakukan, maka tentunya sistem tersebut dapat memberikan dampak positif pada kinerja karyawan. Begitupula dengan kenyamanan fisik saat menggunakan teknologi berbasis komputer. Komputer yang mengalami masalah tentu sangat mengganggu kecepatan dan ketepatan informasi yang diproses. Astuti \& Dharmadiaksa (2014) membuktikan bahwa pekerjaan yang dapat dibantu oleh teknologi yang ada di organisasi mampu menghasilkan kinerja yang diinginkan. Veriana \& Budiartha (2016) dalam hasil penelitiannya menemukan bahwa baiknya teknik dalam pemakaian system informasi akan meningkatkan kinerja karyawan. 
Sebagai teknologi informasi dan komunikasi mencakup berbagai dan mencakup semua bidang di mana perusahaan bertindak, pekerjaan penelitian ini telah difokuskan pada bagian tertentu dari mereka, sistem informasi akuntansi (SIA) untuk menunjukkan bahwa alat akuntansi terkomputerisasi secara langsung berkaitan dengan hasil ekonomi dan keuangan dan produktivitas dalam organisasi bisnis kecil dan menengah. Sistem informasi akuntansi adalah sistem yang digunakan untuk mencatat transaksi keuangan suatu bisnis atau organisasi. Ini adalah mekanisme formal untuk mengumpulkan, mengorganisir dan mengomunikasikan informasi akuntansi tentang kegiatan organisasi. Ini adalah sistem yang memberi orang data atau informasi yang berkaitan dengan operasi organisasi untuk mendukung kegiatan karyawan, pemilik, pelanggan, dan orang-orang penting lainnya di lingkungan organisasi dengan secara efektif menyediakan informasi kepada orang yang berwenang secara tepat waktu (Beg, 2018). Fungsi utamanya adalah untuk memperoleh, memproses, dan mengomunikasikan data yang penting untuk operasi organisasi. Namun demikian, ini adalah entitas, yang terdiri dari berbagai subsistem yang saling bergantung, bekerja bersama untuk menyediakan informasi yang tepat waktu, andal, dan akurat untuk pengambilan keputusan. Ini adalah jaringan yang didirikan dalam suatu organisasi untuk memberikan informasi kepada manajer yang akan membantu mereka dalam pengambilan keputusan. Ini adalah sistem rutin dan otomatis yang digunakan untuk mengumpulkan dan mengkomunikasikan data untuk tujuan membantu dan mengoordinasikan keputusan kolektif mengingat tujuan keseluruhan perusahaan.

Sistem informasi akuntansi yang sukses akan mengarah pada keberhasilan organisasi dalam mencapai tujuannya, tetapi sistem informasi yang tidak berhasil dapat mengarah pada kegagalan organisasi dalam mencapai tujuannya yang berarti ketidakmampuan untuk tumbuh dan bertahan. Sistem ini menggabungkan metodologi, kontrol, dan teknik akuntansi dengan teknologi industri TI: antarmuka pengguna, komputer, dan perangkat lunak canggih. Penelitian ini diharapkan mampu memberikan bukti empiris mengenai pengaruh efektivitas penerapan sistem informasi akuntansi, kesesuaian tugas, dan kenyamanan fisik pada kinerja karyawan Lembaga Perkreditan Desa di Kabupaten Badung.

Sistem Technology Acceptance Model (TAM) menjadi salah satu metode yang dapat digunakan untuk memberikan analisis mengenai faktor yang menjadi penyebab diterima atau tidaknya teknologi informasi berbasis komputer dalam sebuah organisasi. Model ini memfokuskan perhatian pada dua kunci utama yang menjadi alasan pengguna mau menggunakan system baru, yakni manfaat yang diterima dari system tersebut dan kemudahan dalam hal pengoperasiannya. Model TAM merupakan perkembangan dari model yang menjelaskan mengenai perilaku yang didasarkan pada alasan tertentu, dimana bagaimana reaksi seseorang terhadap suatu hal akan menentukan bagaimana orang tersebut akan bersikap. Keterkaitan antara variabel bebas penerapan sistem informasi akuntansi, kesesuaian tugas, dan kenyamanan fisik terhadap variabel terikat kinerja karyawan LPD digambarkan secara jelas dalam model TAM. Model ini berfokus pada efek dari penggunaan komputer pada kinerja 
para karyawan dalam mencapai tujuan organisasi yang telah ditetapkan sebelumnya.

Model TPC menjelaskan bahwa teknologi harus digunakan dan sesuai dengan tugas yang mendukung pengguna untuk mencapai dampak kinerja. Model TPC memberikan gambaran teknologi, tugas pengguna, dan hubungan pemanfaatan yang lebih akurat dengan perubahan kinerja (Abdillah \& Saepullah, 2018). Model teknologi untuk rantai kinerja (TPC) adalah model yang mengukur dampak kinerja dari penggunaan TI oleh individu. Dalam konsep TPC, efek atau efek timbal balik dari hasil kinerja yang baik adalah cerminan dari keberhasilan implementasi atau implementasi sistem informasi. Jadi dapat dengan mudah dijelaskan bahwa kinerja pengguna individu mencerminkan tingkat keberhasilan implementasi sistem yang sedang dijalankan. Menurut Susanti (2006) TPC adalah pernyataan untuk TI yang memiliki pengaruh positif pada kinerja individu, teknologi harus dimanfaatkan dan teknologi harus sesuai dengan tugas yang didukung. Oliveira, et al., (2014) menyebutkan bahwa TPC adalah ukuran teknologi yang membantu individu dalam melaksanakan tugas atau tugas kantor mereka.

Evaluasi sistem informasi akuntansi telah menjadi topik penelitian populer selama bertahun-tahun dalam hal keberhasilan dan efektivitas, yang digunakan secara bergantian. Sistem informasi akuntansi adalah seperangkat kegiatan yang saling tergantung, dokumen, dan teknologi yang dirancang untuk mengumpulkan, memproses, dan melaporkan informasi untuk tujuan pengambilan keputusan (AL-ZOUBI, 2017). Integrasi yang efisien dari aplikasi akuntansi meningkatkan fleksibilitas generasi informasi, meningkatkan kualitas laporan keuangan yang dihasilkan, dan memberikan informasi yang tepat waktu dan andal untuk mendukung perencanaan dan pengambilan keputusan di dalam organisasi. Selain itu, SIA diyakini tidak hanya untuk meningkatkan efektivitas dan efisiensi proses bisnis dan mengurangi biaya tetapi juga untuk menyediakan data real-time yang andal tentang permintaan, memfasilitasi pengetahuan global dan alat pelaporan baru, serta integrasi dan kolaborasi antara bidang-bidang risiko dan operasi bisnis (Fakeeh, 2015).

Sistem informasi akuntansi (SIA) adalah alat yang dapat membantu manajemen organisasi untuk meningkatkan kontrolnya pada operasi perusahaan dan untuk mengembangkan kinerjanya. Sistem Informasi Akuntansi melibatkan Identifikasi, pengumpulan, pemrosesan, dan penyampaian informasi akuntansi kepada karyawan dan pembuat keputusan di semua tingkatan organisasi. Sistem Informasi Akuntansi (SIA) juga dilihat sebagai sistem yang digunakan untuk mencatat transaksi keuangan suatu bisnis atau organisasi. Sistem ini menggabungkan metodologi, kontrol dan teknik akuntansi untuk melacak transaksi keuangan dan untuk menyediakan data pelaporan internal dan eksternal serta membantu penyusunan laporan keuangan dengan kemampuan untuk meningkatkan kinerja organisasi (Estébanez, et al., 2010). Otomatisasi SIA telah memungkinkan akuntan untuk menghasilkan laporan tahunan secara lebih tepat waktu dan akurat. Selain itu, otomatisasi SIA memberikan kesempatan bagi akuntan untuk menyimpang dari peran tradisional menjadi penasihat bisnis (AlEqab \& Adel, 2013). 
Kinerja karyawan dapat meningkat apabila terdapat kesesuaian antara kewajiban dengan teknologi atau sistem yang digunakan. Teknologi yang digunakan dalam organisasi hendaknya sistem yang diterapkan sehingga terdapat keselarasan yang dapat berdampak pada peningkatan kinerja demi mencapai tujuan bersama. Sebagian besar keputusan dan strategi ekonomis untuk memaksimalkan laba dan meminimalkan biaya informasi akuntan. Karena akuntansi mengukur informasi ekonomis dan menawarkannya kepada pengguna dan kita mengetahuinya sebagai sistem informasi, oleh karena itu, manajer memerlukan informasi berkualitas tinggi untuk keberhasilan organisasi. Tugas harus disesuaikan dengan kemampuan masing-masing karyawan yang didukung dengan teknologi informasi yang tersedia (Lindawati, 2012). Kesesuaian tugas dapat dinilai dari seberapa besar individu atau karyawan merasa dibantu oleh adanya teknologi yang diterapkan dalam organisasi (Weyai, 2012). Apabila kewajiban karyawan dapat diselesaikan dengan bantuan dari teknologi, hal ini mengindikasikan bahwa teknologi yang digunakan telah tepat dan sesuai dengan apa yang dibutuhkan organisasi. Sehingga pada akhirnya hal ini akan berdampak pada meningkatnya kinerja maupun pelayanan yang dapat diberikan karyawan.

Selain teknologi yang sesuai, pengguna dari teknologi tersebut perlu diperhatikan demi pencapaian target perusahaan. Dalam hal ini, si pengguna teknologi hendaknya memiliki kenyamanan ketika menerapkan teknologi tersebut, sehingga tugas yang dilakukan bisa semakin baik. Kenyamanan fisik dapat berupa, perlengkapan kantor, mesin-mesin yang dibutukan dalam operasional kantor, tata ruang kantor, dan masih banyak lagi yang dapat mempengaruhi kenyamanan pengguna. Teknologi yang cepat dan tidak mengalami kendala merupakan syarat utama dari kenyamanan fisik.

Kinerja individu adalah segalanya tentang kinerja pekerja di perusahaan atau organisasi atau perusahaan. Bagi organisasi atau pekerja perusahaan, kinerja sangat penting untuk membuat setiap perjuangan untuk mendukung pekerja berkinerja kecil (Fardinal, 2013). Kinerja Karyawan adalah penyelesaian tugas yang berhasil oleh individu atau individu yang dipilih, sebagaimana ditetapkan dan diukur oleh penyelia atau organisasi, hingga standar yang dapat diterima yang telah ditentukan sementara secara efisien dan efektif memanfaatkan sumber daya yang tersedia dalam lingkungan yang berubah (Thach-Thao \& Hwang, 2015). Kinerja karyawan adalah salah satu faktor penting yang berkontribusi signifikan dalam keberhasilan organisasi. Organisasi pembelajaran memainkan peran penting dalam meningkatkan kinerja karyawan melalui penyediaan pelatihan dan pengembangan bagi karyawan mereka (Gitonga, et al., 2016). Kinerja menggabungkan hasil yang dihasilkan dari tindakan yang dilakukan karyawan berdasarkan keahlian dan keterampilan mereka. Dalam pengaturan organisasi, kinerja karyawan adalah hasil akumulasi dari keterampilan, upaya, dan kemampuan semua karyawan yang berkontribusi dalam peningkatan produktivitas organisasi yang mengarah pada pencapaian tujuannya (Dahkoul, 2018).

Lembaga Perkreditan Desa (LPD) menurut Peraturan Daerah Provinsi Bali nomor 3 Tahun 2017 memiliki beberapa cakupan usaha, seperti menghimpun dana dari krama desa, dan memberikan pinjaman kepada krama desa maupun 
krama desa lain atas dasar perjanjian kerjasama yang telah ditetapkan sebelumnya dengan desa lain. Tujuan dibentuknya LPD pada dasarnya adalah untuk membantu perekonomian krama desa yang mengalami kesulitan ekonomi, dan membantu krama desa yang membutuhkan bantuan dana sebagai modal usaha.

Efektivitas menunjukkan tercapainya tujuan organisasi sebagai hasil dari kinerja yang baik dari kerjasama antar karyawan dengan elemen-elemen pendukung seperti teknologi. Sistem informasi akuntansi telah diakui sebagai alat yang efektif untuk mencapai tidak hanya perubahan internal tetapi juga perubahan organisasi eksternal. Karena itu, banyak organisasi, tetapi terutama bank, tidak memiliki pilihan lain selain berinvestasi dalam teknologi terbaru seperti Sistem Informasi Akuntansi (SIA) untuk memenuhi kebutuhan pelanggan mereka dan bersaing dengan baik. Model TAM pengguna teknologi informasi akan dapat menerima teknologi baru apabila memenuhi salah satu dari dua persepsi, yakni persepsi bahwa teknologi tersebut bermanfaat untuk membantu penyelesaian tugasnya, dan persepi bahwa teknologi tersebut mudah untuk digunakan. Kesimpulannya adalah semakin efektif pengguna menggunakan teknologi informasi, maka semakin efektif pula hasil kerja dari pengguna (Pratama \& Suardikha, 2013).

Penelitian terdauhulu oleh Awosejo, et al., (2013), Suratini, et al., (2015), dan Antasari \& Yaniartha (2015) menunjukkan hasil bahwa efektivitas penerapan sistem informasi akuntansi memberikan pengaruh positif pada kinerja individual dalam suatu organisasi. Uraian di atas memberikan pernyataan hipotesis pertama yakni.

$\mathrm{H}_{1}$ : Efektivitas penerapan sistem informasi akuntansi berpengaruh positif pada kinerja karyawan.

Kesesuaian tugas menunjukkan kemampuan yang dimiliki karyawan untuk menerapkan dan memanfaatkan teknologi informasi dengan baik sehingga dapat meningkatkan kinerjanya (Rahmawati, 2019). Dalam Technologyto-Performance Chain (TPC), disebutkan pentingnya kesesuaian tugas dengan teknologi yang diterapkan dalam sebuah organisasi akan berdampak pada pencapaian akhir dari tujuan organisasi. Teknologi yang disediakan organisasi, apabila sesuai dengan tugas-tugas yang akan dilakukan oleh karyawan, maka akan terjadi keselarasan dan karyawan akan merasa tugasnya dipermudah dan dibantu atas adanya teknologi tersebut, sehingga hal ini memungkinkan karyawan untuk berkinerja lebih baik lagi.

Penelitian oleh Nurmalitasari (2010) dan Ashianti \& Fani (2013) menunjukkan adanya pengaruh antara kesesuaian tugas dengan teknologi informasi pada kinerja individu. Pengaruh yang diberikan adalah pengaruh positif, dimana kinerja yang baik dapat menjadi dampak dari adanya kesesuaian tugas dengan penerapan teknologi. Berdasarkan hal tersebut, maka dapat dirumuskan hipotesis sebagai berikut.

$\mathrm{H}_{2}$ : Kesesuaian tugas dengan teknologi informasi berpengaruh positif pada kinerja karyawan.

Model TAM memberikan dua persepsi yang biasanya digunakan individu yakni persepsi bahwa teknologi bermanfaat untuk dirinya, dan persepsi bwah teknologi yang digunakan mudah untuk diterapkan. Kebermanfaatan dan 
kemudahan dalam pengaplikasian teknologi ini berhubungan erat dengan kenyamanan fisik yang dirasakan oleh karyawan. Lingkungan kerja yang bak, kultur organisasi yang dapat diterima individu dapat menciptakan kenyamanan bagi karyawan dalam melaksanakan tugasnya. Teknologi yang sesuai dengan tugas berarti pengguna teknologi tersebut merasakan kenyamanan dalam penggunaannya sehingga mampu memanfastkan teknologi yang ada dengan sebagaimana mestinya.

Menurut Astuti \& Dharmadiaksa (2014) dalam penelitiannya menunjukkan hasil bahwa apabila karyawan menerima kenyamanan fisik maka mereka cenderung akan lebi fokus dalam melakukan tugas-tugasnya. Uraian tersebut merumuskan hipotesis ketiga sebagai berikut.

$\mathrm{H}_{3}$ : Kenyamanan fisik berpengaruh positif pada kinerja karyawan.

\section{METODE PENELITIAN}

Desain penelitian adalah pedoman atau prosedur serta teknik dalam perencanaan penelitian yang berguna sebagai panduan untuk membangun strategi yang menghasilkan model atau blue print penelitian. Kualitas penelitian dan ketepatan penelitian antara lain ditentukan oleh desian penelitian yang dipakai. Oleh karena itu desain yang dipergunakan dalam penelitian harus desain yang tepat. Secara sistematis, desain penelitian yang digunakan pada penelitian ini dapat digambarkan sebagai berikut.
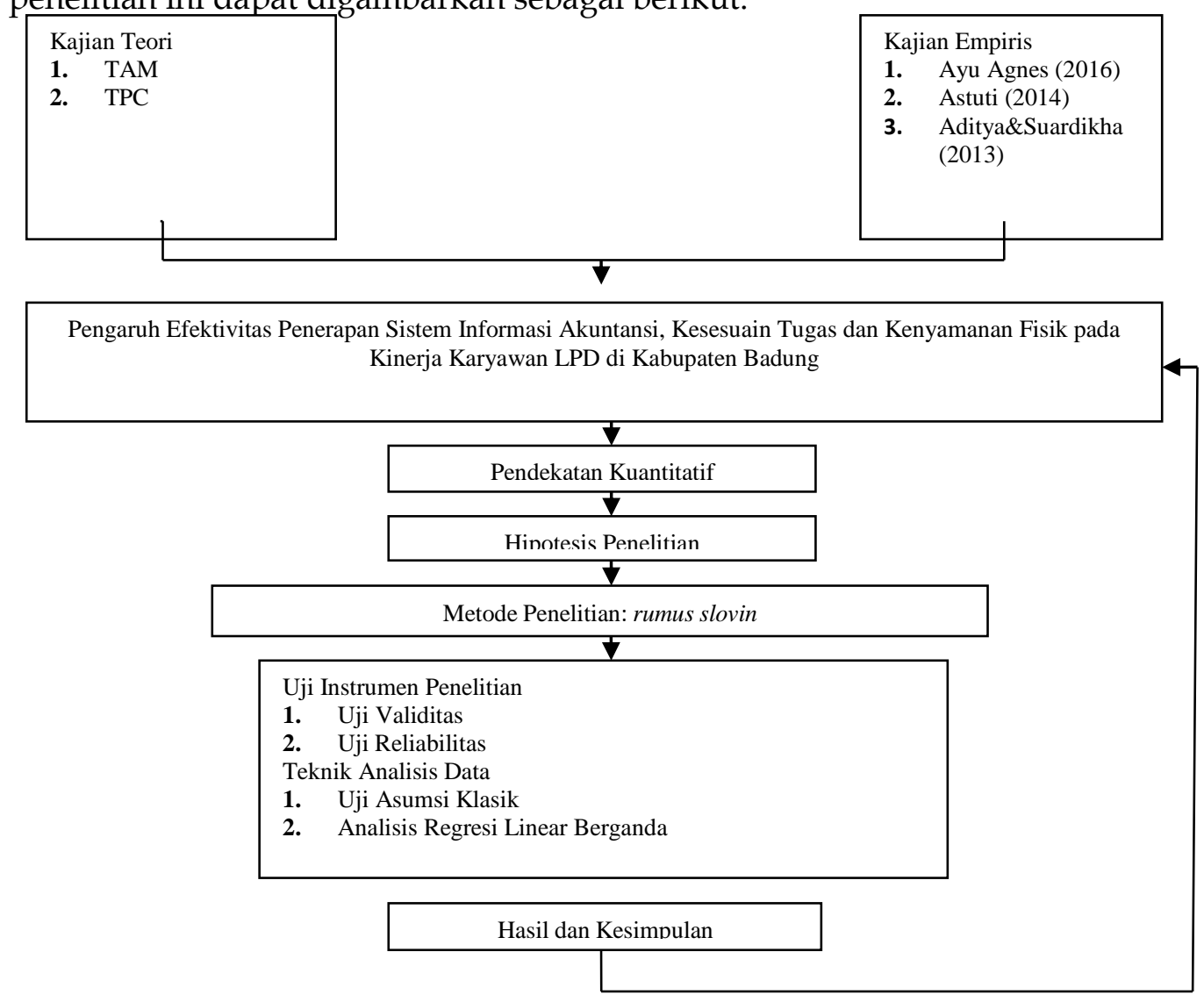

Sumber : Data Penelitian, 2019

\section{Gambar 1. Desain Penelitian}


Penelitian ini dilakukan di LPD Kabupaten Badung, karena berdasarkan data LPLPD Badung, sebagian besar LPD di Kabupaten Badung telah menggunakan teknologi informasi dalam pengolahan datanya yaitu 85 LPD atau $70 \%$. Sistem informasi akuntansi berbasis komputer yang digunakan oleh LPD Badung pada umumnya yaitu Gio Shop yang telah digunakan sejak tahun 2015. Selain itu data LP-LPD Ferbruari 2018 menunjukkan bahwa dari segi jumlah aset LPD Kabupaten Badung menempati peringkat 1 yang berarti bahwa LPD Kabupaten Badung dikelola dengan sangat baik dibandingkan dengan di kabupaten lain di Provinsi Bali.

Populasi dalam penelitian berjumlah 366 orang, yaitu karyawan di LPD Kabupaten Karangasem yang telah menggunakan sistem informasi. peneliti menggunakan rumus slovin untuk memperkecil jumlah populasi yang terlalu banyak. Sesuai dengan rumus slovin, maka jumlah sampel dalam penelitian ini adalah 191 orang. Kuesioner dan observasi terstruktur merupakan metode yang digunakan dalam penelitian. Teknik analisis data menggunakan regresi linear berganda, dengan rumus seperti yang ditunjukkan berikut.

$Y=\alpha+\beta_{1} X_{1}+\beta_{2} X_{2}+\beta_{3} X_{3}+e$

Keterangan:

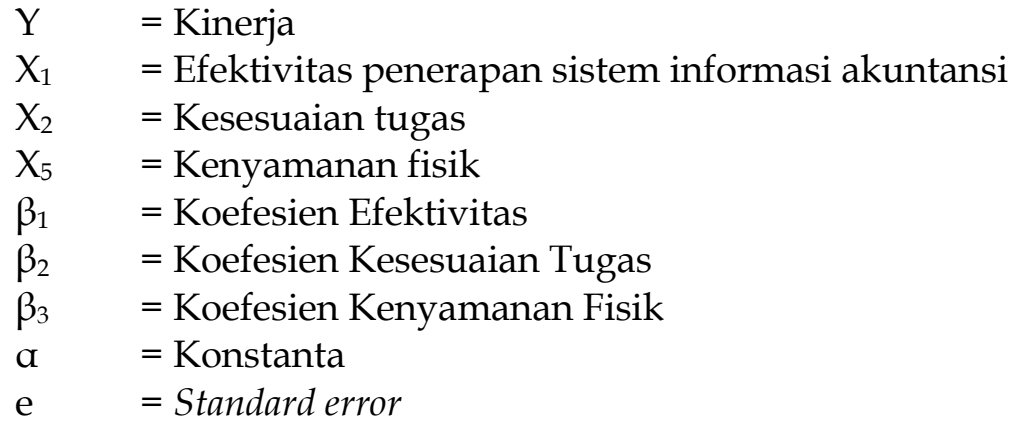

\section{HASIL DAN PEMBAHASAN}

Peneliti melakukan observasi dengan memberikan kuesioner kepada pihak yang telah ditunjuk sebagai sampel di masing-masing LPD di Kabupaten Badung, dimana masing-masing LPD diberikan tiga buah kuesioner sesuai dengan jumlah sampel yang diambil yaitu 3 orang karyawan LPD yang terlibat langsung dengan SIA. Berikut rincian penyebaran kuesioner pada tabel 2.

\section{Tabel 2. Data Kuesioner}

\begin{tabular}{lc}
\hline \multicolumn{1}{c}{ Keterangan } & Jumlah \\
\hline Total kuesioner yang disebar & 195 \\
Kuesioner yang tidak kembali & 3 \\
Kuesioner yang dikembalikan & 192 \\
Kuesioner yang tidak dapat digunakan & 1 \\
Kuesioner yang digunakan dalam anlisis & 191 \\
Tingkat pengembalian : & $98,5 \%$ \\
Kuesioner yang dikembalikan X 100\% & \\
\hline $\begin{array}{l}\text { Kuesiner yang disebar } \\
\text { Tingkan pengembalian yang digunakan : }\end{array}$ & $99,5 \%$ \\
Kuesioner yang digunakan X 100\% & \\
Kuesioner yang disebar &
\end{tabular}


Tabel 2. menunjukkan bahwa sebanyak 195 kuesioner disebarkan di LPD Kabupaten Badung, dimana sebanyak 192 kuesioner kembali, dan sisanya sebanyak 3 kuesioner tidak kembali. Terdapat 1 kuesioner yang tidak dapat digunakan karena tidak sesuai dengan kriteria yang ditentukan. Jumlah kuesioner yang memenuhi kriteria dan digunakan sebanyak 191 kuesioner.

Validitas berasal dari kata validity yang mempunyai arti sejauh mana ketepatan dan kecermatan suatu alat ukur dalam melakukam fungsi ukurannya. Suatu tes dapat dikatakan memiliki validitas yang tinggi jika tes tersebut menjalankan fungsi ukurnya, atau memberikan hasil ukur yang tepat dan akurat sesuai dengan maksud dikenakannya tes tersebut. Suatu tes menghasilkan data yang tidak relevan dengan tujuan diadakannya pengukuran dikatakan sebagai tes yang memiliki validitas rendah. Suatu alat ukur yang valid dapat menjalankan fungsi ukurnya dengan tepat, juga memiliki kecermatan tinggi. Uji validitas dilakukan dengan menghitung korelasi antara skor masing-masing butir pertanyaan dengan total skor sehingga diperoleh nilai Person Cor-relation. Hasil uji validitas dapat dilihat pada Tabel 3. berikut.

Tabel 3. Hasil Uji Validitas

\begin{tabular}{|c|c|c|c|c|}
\hline No & Variabel & Indikator & $\begin{array}{c}\text { Nilai Pearson } \\
\text { Correlation }\end{array}$ & Keterangan \\
\hline \multirow{5}{*}{1} & \multirow[b]{5}{*}{ Efektivitas Penerapan SIA (X1) } & X1.1 & 0,765 & Valid \\
\hline & & X1.2 & 0,797 & Valid \\
\hline & & X1.3 & 0,852 & Valid \\
\hline & & X1.4 & 0,789 & Valid \\
\hline & & X1.5 & 0,762 & Valid \\
\hline \multirow{5}{*}{2} & & $X 2.1$ & 0,721 & Valid \\
\hline & & $X 2.2$ & 0,657 & Valid \\
\hline & & $X 2.3$ & 0,743 & Valid \\
\hline & & $X 2.4$ & 0,724 & Valid \\
\hline & Kesesuaian Tugas (X2) & $X 2.5$ & 0,715 & Valid \\
\hline \multirow{4}{*}{3} & & X3.1 & 0,687 & Valid \\
\hline & & X3.2 & 0,660 & Valid \\
\hline & & X3.3 & 0,711 & Valid \\
\hline & Kenyamanan Fisik (X3) & X3.4 & 0,677 & Valid \\
\hline \multirow{4}{*}{4} & & Y.1 & 0,801 & Valid \\
\hline & & Y.2 & 0,801 & Valid \\
\hline & & Y.3 & 0,787 & Valid \\
\hline & Kinerja Karyawan (Y) & Y.4 & 0,865 & Valid \\
\hline
\end{tabular}

Sumber : Data Penelitian, 2019

Dapat disimpulkan bahwa instrumen dalam penelitian ini memiliki nilai koefisien korelasi dengan skor total seluruh item pernyataan bernilai positif dan lebih besar dari 0,30. Hal ini menunjukkan bahwa setiap pernyataan dalam instrumen penelitian tersebut valid.

Uji reliabilitas terpenuhi apabila nilai cronbach's alpha $>0,60$, dimana dalam penelitian, hal ini dapat dilihat pada tabel 4 . 
Tabel 4. Hasil Uji Reliabilitas

\begin{tabular}{llll}
\hline \multirow{2}{*}{ No } & Variabel & Cronbach's Alpha & Keterangan \\
& & & \\
\hline 1 & Efektivitas Penerapan SIA (X1) & 0,852 & Reliabel \\
2 & Kesesuaian Tugas (X2) & 0,754 & Reliabel \\
3 & Kenyamanan Fisik(X3) & 0,616 & Reliabel \\
4 & Kinerja Karyawan (Y) & 0,828 & Reliabel \\
\hline
\end{tabular}

Sumber : Data Penelitian, 2019

Analisis statistik deskriptif memberikan gambaran informasi yang dilihat dari beberapa hal, seperti rata-rata, nilai maksimum dan minimum, serta standar deviasi dari data penelitian yang bisa dilihat pada tabel 5 . berikut.

Tabel 5. Hasil Statistik Deskriptif

\begin{tabular}{lccccc}
\hline \multicolumn{1}{c}{ Variabel } & N & Min. & Max. & Mean & $\begin{array}{c}\text { Std. } \\
\text { Devisiasi }\end{array}$ \\
\hline Efektivitas (X1) & 191 & 10 & 20 & 16,20 & 2,527 \\
Kesesuaian Tugas (X2) & 191 & 10 & 20 & 16,22 & 4.810 \\
Kenyamanan Fisik (X3) & 191 & 8 & 16 & 12,32 & 3.942 \\
Kinerja Karyawan (Y) & 191 & 8 & 16 & 12,78 & 3.5 .79 \\
\hline
\end{tabular}

Sumber : Data Penelitian, 2019

Variabel Efektivitas Penerapan SIA nilai rata-ratanya 16,20 mendekati nilai maksimum 20, menunjukkan keseluruhan karyawan telah menggunakan teknologi informasi secara efektif. Variabel kesesuaian tugas menunjukkan nilai rata-rata 16,22 dimana hal ini juga hampir menyentuh nilai maksimum 20, memperlihatkan bahwa kinerja karyawan telah memperoleh tugas yang sesuai. Variabel kenyamanan fisik nilai rata-ratanya adalah sebesar 12,32 mendekati nilai maksimum 16 menggambarkan bahwa keseluruhan karyawan telah memiliki kenyamanan fisik dalam bekerja.

Uji Normalitas adalah sebuah uji yang dilakukan dengan tujuan untuk menilai sebaran data pada sebuah kelompok data atau variabel, apakah sebaran data tersebut berdistribusi normal ataukah tidak. Uji Normalitas berguna untuk menentukan data yang telah dikumpulkan berdistribusi normal atau diambil dari populasi normal. Uji normalitas bertujuan untuk mengetahui normal atau tidaknya distribusi variabel residual. Penelitian layak digunakan apabila variabel residual berdistribusi normal, yang ditunjukkan dengan nilai Asymp. Sig (2tailed $>>$ a. $(0,05)$, seperti tabel 6 . berikut ini.

\section{Tabel 6. Hasil Uji Normalitas}

\begin{tabular}{llr}
\hline $\mathrm{N}$ & & Unstandardized Residual \\
Normal Parameters & & 191 \\
& Mean &, 0000000 \\
Most Extreme Differences & Std. Deviation & 1,54083669 \\
& Absolute & 0,083 \\
& Positive & 0,061 \\
& Negative &,- 083 \\
Kolmogorov-Smirnov Z & & 1,143 \\
Asymp. Sig. (2-tailed) & & 0,147 \\
\hline Sumber : Data Penelitian, 2019 & &
\end{tabular}


Hasil uji normalitas yang menggunakan model regresi menunjukkan bahwa nilai residual berdisitribuasi normal karena nilai signifikansi 0,147 berada di atas nilai yang disyaratkan 0,05, sehingga dikatakan layak untuk uji.

Uji multikoliniearitas untuk menguji ada tidaknya multikoliniearitas dalam penelitian, dimana model penelitian disyaratkan untuk tidak memiliki multikolinearitas.

\section{Tabel 7. Hasil Uji Multikolinearitas}

\begin{tabular}{|c|c|c|c|}
\hline & \multicolumn{2}{|c|}{ Collinearity Statistics } \\
\hline & & Tolerance & VIF \\
\hline \multirow[t]{4}{*}{1} & (Constant) & & \\
\hline & Efektivitas Penerapan SIA & 0,488 & 2,048 \\
\hline & Kesesuaian Tugas & 0,495 & 2,018 \\
\hline & Kenyamanan Fisik & 0,827 & 1,210 \\
\hline
\end{tabular}

Sumber: Data Penelitian, 2019

Dilihat dari Tabel 7. dapat ditarik kesimpulan bahwa ketiga variabel tidak memiliki multikolinearitas karena nilai tolerance dan VIF nya telah memenuhi persyaratan yaitu di atas 10 persen untuk nilai tolerance, dan $\mathrm{d}$ bawah 10 untuk VIF.

Uji heteroskedastisitas untuk menentuk ada tidaknya kesamaan varian antar variabel bebas yang dilakukan dengan uji glejser, dimana persyaratannya adalah nilai signifikansinya lebih besar dari $\alpha=0,05$, maka tidak terjadi gejala heteroskedastisitas. Tabel 8. Menunjukkan hasil uji heteroskedastisitas.

Tabel 8. Hasil Uji Heteroskedastisitas

\begin{tabular}{llr}
\multicolumn{2}{c}{ Model } & Sig. \\
\hline 1 & (Constant) & 0,563 \\
Efektivitas Penerapan SIA & 0,206 \\
Kesesuaian Tugas & 0,871 \\
& Kenyamanan Fisik & 0,643 \\
\hline
\end{tabular}

Sumber: Data Penelitian, 2019

Berdasarkan tabel 8. dapat disimpulkan bahwa model penelitian ini tidak mengandung heteroskedastisitas karena nilai signifikansi telah memenuhi kriteria yaitu berada di atas 0,05 .

Analisis linier berganda bertujuan untuk menjawab pertanyaan bagaimana pengaruh variabel bebas jika dihubungkan dengan variabel terikatnya, yang pada penelitian ini dapat kita analisis melalui tabel 9.

Tabel 9. Hasil Analisis Regresi Linier Berganda

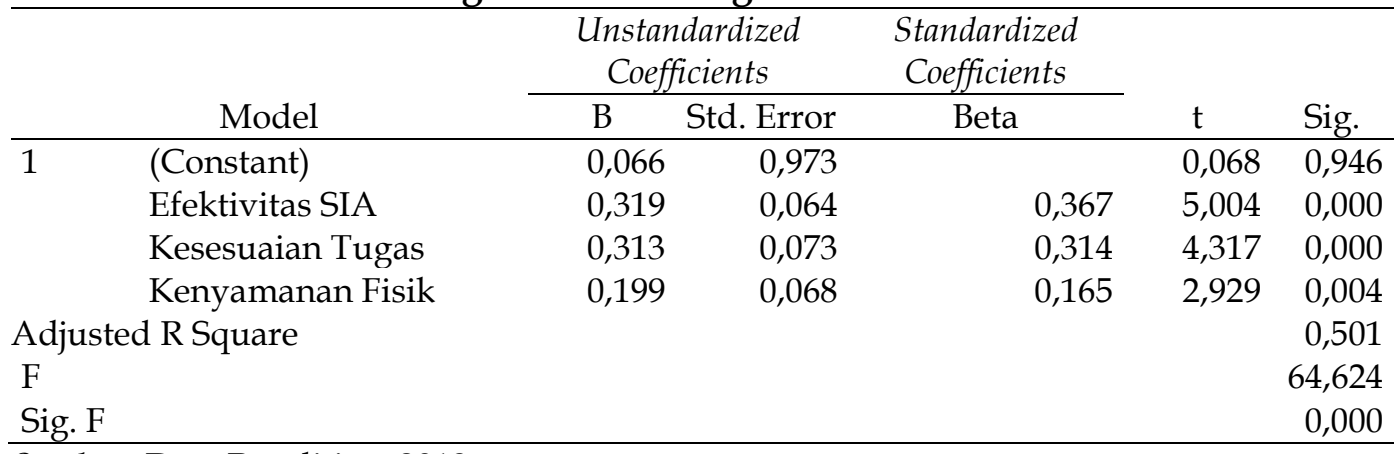

Sumber : Data Penelitian, 2019 
Berdasarkan tabel 9. dapat diketahui rumusan regresi linear berganda sebagai berikut.

$$
\mathrm{Y}=0,066+0,319 \mathrm{X} 1+0,313 \mathrm{X} 2+0,199 \mathrm{X} 3+\mathrm{e}
$$

Nilai konstanta (a) 0,066 memiliki arti jika variabel efektivitas penerapan SIA $\left(\mathrm{X}_{1}\right)$, kesesuaian tugas $\left(\mathrm{X}_{2}\right)$, kenyamanan fisik $\left(\mathrm{X}_{3}\right)$ bertambah, maka $(\mathrm{Y})$ cenderung meningkat. Nilai koefesien $\beta_{1}$ pada variabel efektivitas penerapan SIA bernilai positif maka efektivitas penerapan SIA $\left(X_{1}\right)$ akan cenderung meningkat. Nilai koefesien $\beta_{2}$ pada variabel kesesuaian tugas bernilai positif, maka kesesuaian tugas $\left(X_{2}\right)$ akan cenderung meningkat. Nilai koefesien $\beta_{3}$ pada variabel kenyamanan fisik bernilai positif maka kenyamanan fisik $\left(X_{3}\right)$ akan cenderung meningkat.

Nilai adjusted $R$ Square adalah 0,501 atau $50,1 \%$, ini berarti sebesar 50,1\% variasi kinerja dipengaruhi oleh efektivitas penerapan SIA, kesesuaian tugas, kenyamanan fisik. Sedangkan sisanya sebesar 49,9\% dipengaruhi oleh faktor lain yang tidak dimasukkan didalam penelitian ini.

Tabel 9. juga memberikan petunjuk bahwa model penelitian memiliki kelayakan untuk menjadi alat analisis pengaurh variabel-variabel dalam penelitian, sebab nilai signifikansi yang diperoleh telah sesuai dengan yang disyaratkan yakni kurang dari nilai alpha 0,05. Nilai tersebut juga memberikan pernyataan bahwa variabel-variabel bebas dalam penelitian ini secara bersamasama mempengaruhi kinerja karyawan.

Hipotesis pertama dalam penelitian dapat diterima berdasarkan nilai signifikansi variabel penerapan SIA yang kurang dari alpha 0,05. Diterimanya hipotesis pertama ini sesuai dengan yang dinyatakan dalam teori Technology Acceptance Model (TAM) yang berpendapat bahwa teknologi yang diterapkan dan dilakukan oleh karyawan sebuah organsiasi didasarkan pada dua persepsi yaitu keyakinan bahwa teknologi tersebut bermanfaat dalam membantu melaksanakan tugasnya, dan keyakinan bahwa teknologi tersebut mudah untuk digunakan dan diaplikasikan. Suatu sistem informasi diterapkan dengan baik maka akan memberikan manfaat bagi karyawan LPD dalam meningkatkan kinerjanya, seperti software yang digunakan dalam mengolah data. Penggunaan sistem informasi akuntansi harus didukung dengan kemampuan personal pemakai sistem tersebut, sehingga SIA dapat berjalan secara efektif dan mampu meningkatkan kinerja LPD dan kinerja karyawannya. Kemampuan personal dapat dilihat berdasarkan lama bekerja. Karyawan yang memiliki pengalaman kerja lebih lama cenderung memiliki kemampuan kerja yang lebih baik dibandingkan dengan karyawan yang baru bekerja, hal ini dikarenakan karyawan yang memiliki pengalaman kerja lebih lama telah memahami semua aturan yang diterapkan serta pekerjaan yang dilakukan. Penelitian-penelitian yang memiliki hasil serupa dengan penelitian ini adalah (Suratini et al., 2015) dan (Antasari \& Yaniartha, 2015).

Layaknya hipotesis pertama, hipotesis kedua dalam penelitian ini juga diterima sesuai dengan nilai signifikansi variabel kesesuaian tugas yang kurang dari nilai alpa 0,05 sesuai persyaratan. Peneriman hipotesis kedua ini sejalan dengan pernyataan dalam teori Technology to Performance Chain (TPC) bahwa teknologi yang akan diaplikasikan dalam sebuah organisasi harus sesuai dengan 
tugas yang dilakukan karyawan, sehingga terdapat keselarasan antara kewajiban karyawan dengan teknologi yang dapat mendukung penyelesaian kewajibannya. Melalui model TPC ini, kita dapat menganalisis seberapa krusial manfaat penggunaan teknologi sistem informasi pada kinerja karyawan, atau apakah teknologi yang digunakan mampu menghasilkan hasil yang lebih baik dari sebelum penerapannya. Kesesuaian tugas berhubungan dengan sejauh mana kemampuan karyawan LPD dalam menggunakan teknologi infomasi untuk mengerjakan tugas-tugasnya. Keakuratan, aksesibilitas, tingkat rincian yang tepat serta kemudahan menggunakan perangkat keras dan lunak juga mempengaruhi kinerja karyawan LPD dalam mengerjakan tugasnya. Penelitian yang mendukung hasil ini adalah (Syahroni, 2014) dan (Saputri, 2013).

Hipotesis ketiga dalam penelitian ini diterima dengan nilai signifikansi 0,004 kurang dari nilai alpha 0,05. Kenyamanan tidak semata mata berarti kondisi fisik karyawan, melainkan lebih ke kemudahan dalam aplikasi teknologi dan mesin dalam lembaga, kelengkapan sarana dan prasarana komputer, tata ruang yang sesuai dengan cara kerja. Karyawan LPD yang memiliki rasa nyaman ketika menggunakan teknologi, tentunya akan membuat mereka semakin fokus dalam melaksanakan tugasnya. Berdasarkan hasil penelitian kecamatan yang memiliki tingkat kenyamanan fisik paling rendah yaitu kecamatan Petang, hal ini dikarenakan perkembangan teknologi yang semakin pesat cenderung memusat di Badung Selatan seperti kecamatan Kuta. Kinerja karyawan yang didukung oleh kelengkapan peralatan komputer, kelengkapan aplikasi pada komputer, kondisi perangkat komputer dan keamanan data dapat meningkatkan kinerja karyawan LPD tersebut sehingga adanya rasa nyaman dalam bekerja dan dapat dipastikan bahwa produktivitas akan meningkat. Produktivitas karyawan juga dapat dilihat dari usia. Karyawan yang memiliki usia $>40$ tahun pada umumnya kurang produktif dalam menggunakan sistem terkomputerisasi pada pengolahan data. Sehingga usia karyawan sangat menentukan apakah karyawan tersebut memiliki produktivitas kerja yang tinggi atau rendah. Hasil penelitian ini mendukung hasil penelitian yang dilakukan oleh (Ashianti \& Fani, 2013), (Kurnia, 2019) dan (Muawanah, et al., 2016).

\section{SIMPULAN}

Efektivitas penerapan sistem informasi akuntansi berpengaruh positif terhadap kinerja karyawan. Hal ini berarti bahwa efektivitas penerapan sistem informasi akuntansi yang semakin baik pada LPD di Kabupaten Badung akan meningkatkan kinerja karyawan dalam mengerjakan tugasnya. Kesesuaian tugas dengan teknologi informasi berpengaruh positif terhadap kinerja karyawan. Ini berarti bahwa kesesuaian tugas dan teknologi informasi yang tinggi serta apabila diterapkan dengan baik pada setiap karyawan akan meningkatkan tingkat kinerja karyawan. Kenyamanan fisik mempunyai pengaruh yang positif terhadap kinerja karyawan. Hal ini berarti bahwa kenyamanan fisik yang tinggi terhadap peralatan kerja (perangkat komputer dan sebagainya) yang baik serta kemudahan pengguna (user) dalam mencari data yang diperlukan untuk menyelesaikan tugas pada setiap karyawan meningkatkan tindakan untuk melakukan kinerja yang semakin baik. 


\section{REFERENSI}

Abdillah, W., \& Saepullah, A. (2018). Model Technology to Performance Chain (TPC) in Implementing Accrual-Based Sistem Informasi Manajemen Daerah (SIMDA) Finance: Empirical Evidence from Local Government of Indonesia. Jurnal Dinamika Manajemen, 9(1), 56-68. https://doi.org/10.15294/jdm.v9i1.14652

Al-Eqab; Adel. (2013). The Impact of IT Sophistications on the Perceived Usefulness of Accounting Information Characteristics among Jordanian Listed Companies Mahmoud Al-Eqab College of Bussiness Adminstration Prince Sultan University Riyadh, Kingdome of Saudi Arabia College o. International Journal of Business and Social Science, 4(3), 145-155. https://doi.org/10.1016/j.triboint.2013.05.005

AL-ZOUBI, A. M. (2017). The Extent of Electronic Accounting Information Systemsâ $\square^{\mathrm{TM}}$ Ability to Provide Quantitative Indicators of Financial Performance in both Public and Private Universities in Jordan. International Journal of Academic Research in Accounting, Finance and Management Sciences, 7(3), 97-107. https:// doi.org/10.6007/ijarafms/v7-i3/3178

Antasari, K. C., \& Yaniartha, P. D. (2015). Pengaruh Efektivitas Sistem Informasi Akuntansi Dan Penggunaan Teknologi Informasi Pada Kinerja Individual Dengan Kepuasan Kerja Sebagai Variabel Pemoderasi. Fakultas Ekonomi Dan Bisnis Universitas Udayana, 10(2), 354-369. Retrieved from https://ojs.unud.ac.id/index.php/Akuntansi/article/view/9985

Ashianti, A., \& Fani, A. (2013). Pengaruh Kesesuaian Tugas-Teknologi, Kepercayaan dan Efektivitas Sistem Informasi Akuntansi Terhadap Kinerja Individu pada Pasar Swalayan di Kota Tangerang. Jurnal ULTIMA Accounting, 5(2), 62-80. https:// doi.org/10.31937/akuntansi.v5i2.152

Astuti, N. M. M. P., \& Dharmadiaksa, I. B. (2014). Pengaruh Efektivitas Penerapan SIA, Pemanfaatan, dan Kesesuaian Tugas pada Kinerja Karyawan. E-Jurnal Akuntansi Universitas Udayana, 7(3), 747-753.

Awosejo, O. J., Kekwaletswe, Pretorius, \& Zuva. (2013). The Effect of Accounting Information Systems in Accounting. International Journal of Advanced Computer Research, 3(3), 2249-7277.

Beg, K. (2018). Impact of Accounting Information System on the Financial Performance of Selected FMCG Companies. Asian Journal of Applied Science and Technology (AJAST) (Open Access Quarterly International Journal, 2(3), 817. Retrieved from www.ajast.net

Dahkoul, Z. M. (2018). The determinants of employee performance in Jordanian organizations. Journal of Economics, Finance, and Accounting, 5(1), 11-17. https://doi.org/10.17261/pressacademia.2018.780

Davis, F. D. (1989). Perceived Usefulness, Perceived Ease of Use, and User Acceptance of Information Technology. MIS Quarterly, 13(3), 319-340. https://doi.org/10.2307/249008

Edison, G., Manuere, F., Joseph, M., \& Gutu, K. (2012). Evaluation of Factors Influencing Adoption of Accounting Information System By Small to Medium Enterprise in Chinhoyi. Interdisciplinary Journal Of Contemporary Research In Business, 4(6), 1126-1141.

Fakeeh, K. A. (2015). The Practice and Prospects of Accounting Information 
Systems (AIS). International Journal of Applied Information Systems, 10(3), 1622. https:// doi.org/10.5120/ijais2015451475

Fardinal. (2013). The Quality of Accounting Information and The Accounting Information System through The Internal Control Systems: A Study on Ministry and State Agencies of The Republic of Indonesia. Research Journal of Finance and Accounting, 4(6), 156-161.

Gitonga, M. K., Kingi, \& Jean. (2016). Determinants of Employees Performance in. International Academic Journal of Human Resource and Business Administration, 2(2), 208-222.

Indralesmana, K. W., \& Suaryana, I. G. . A. (2014). Pengaruh Penerapan Sistem Informasi Akuntansi erhadap Kinerja Individu pada Usaha Kecil dan Menengah di Nusa Penida. E-Jurnal Akuntansi Universitas Udyana, 7(2), 345356.

Kurnia, I. Y. (2019). Pengaruh Keahlian Pemakai Komputer, Kenyamanan Fisik, Kesesuaian Tugas, dan Pemanfaatan Teknologi Informasi terhadap Kinerja Karyawan (Survey pada PT Pupuk Kujang Cikampek). Skripsi. Universitas Pasundan: Bandung.

Lindawati, H. dan I. S. (2012). Pemanfaatan Sistem Informasi dan Teknologi Informasi Pengaruhnya Terhadap Kinerja Individual Karyawan. Jurnal Akuntansi Dan Keuangan, 14(1), 56-68.

Muawanah, S. N., Mutmainah, K., \& Romandhon. (2016). Pengaruh Efektivitas Penggunaan Sistem Informasi Akuntansi, Kepercayaan terhadap Sistem Informasi Akuntansi, Kemampuan Teknik Pemakai Sistem Informasi Akuntansi dan Kenyamanan Fisik terhadap Kinerja Individu. Jurnal Fakultas Ekonomi Universitas Sains Al-Qur'an, 11(2), 1-23.

Nurmalitasari, M. D. (2010). Pengaruh Kesesuaian Tugas-Teknologi, Keahlian Pengguna, Dan Pemanfaatan Teknologi Informasi Terhadap Kinerja Karyawan. Skripsi. Sarjana Jurusan Akuntansi Fakultas Ekonomi Universitas Muhammadiyah Surakarta.

Ochoti, G. N., Maronga, E., Muathe, S., Nyabwanga, R. N., \& Ronoh, P. K. (2012). Factors Influencing Employee Performance Appraisal System: A Case of the Ministry of State for Provincial Administration \& Internal Security , Kenya. International Journal of Business and Social Science, 3(20), 37-46. https://doi.org/10.5296/jpag.v2i4.2751

Oliveira, T., Faria, M., Thomas, M. A., \& Popovič, A. (2014). Extending the understanding of mobile banking adoption: When UTAUT meets TTF and ITM. International Journal of Information Management, 34(5), 689-703. https://doi.org/10.1016/j.ijinfomgt.2014.06.004

Pérez Estébanez, R., Urquía Grande, E., \& Muñoz Colomina, C. (2010). Information technology implementation: Evidence in Spanish SMEs. International Journal of Accounting \& Information Management, 18(1), 39-57. https:// doi.org/10.1108/18347641011023270

Pratama, G. A., \& Suardikha, I. M. S. (2013). Keahlian Pemakai Komputer dan Kenyamanan Fisik dan Tingkat Efektivitas Sistem Informasi Akuntansi Terhadap Kinerja Karyawan. E-Jurnal Akuntansi Universitas Udyana, 5(2), 361-381.

Rahmawati, D. (2019). Analisis Faktor Faktor yang Berpengaruh Terhadap 
Pemanfaatan Teknologi Informasi. Jurnal Ekonomi Dan Pendidikan, 5(1), 107118. https:// doi.org/10.21831/jep.v5i1.606

Saputri, S. R. (2013). Pengaruh Kesesuaian Tugas Teknologi, Kepercayaan, dan Pemanfaatan Teknologi Informasi terhadap Kinerja Karyawan (Studi pada Karyawan Bank Rakyat Indonesia Kantor Cabang Karanganyar). Skripsi. Sarjana Jurusan Akuntansi Fakultas Ekonomi dna Bisnis Universitas Muhammadiyah Surakarta.

Suratini, N. P. E. S., Sinarwati, N. K., \& Atmadja, A. W. T. (2015). Pengaruh Efektivitas Sistem Informasi Akuntansi dan Penggunaan Teknologi Informasi Akuntansi terhadap Kinerja Individual pada PT. Bannk Pembangunan Daerah Bali Kantor Cabang Singaeaja. E-Journal S1 Ak Universitas Pendidikan Ganesha, 3(1).

Susanti, V. A. (2006). Teknologi Tugas Yang Fit Dan Kinerja Individual. Jurnal Manajemen, Akuntansi, Dan Sistem INnformasi, 6(2), 224-242.

Syahroni, K. H. (2014). Pengaruh Pemanfaatan Teknologi Informasi, Kesesuaian Tugas-Teknologi Informasi, dan Kepercayaan Atas Teknologi Informasi terhadap Kinerja Individual. Skripsi. Sarjana Jurusan Akuntansi Fakultas Ekonomi dan Bisnis Universitas Muhammadiyah Surakarta. https://doi.org/http://dx.doi.org/110.21043/equilibrium.v3i2.1268

Thach-Thao, L. T., \& Hwang, C. J. (2015). Factors Affecting Employee Performance - Evidence From Petrovietnam Engineering. Meiho University Institusional Repository. Retrieved from http://ir.meiho.edu.tw/ir/handle/987654321/2774

Veriana, P. A. A., \& Budiartha, I. K. (2016). Pengaruh Efektivitas Penerapan Sistem Informasi Akuntansi, Budaya Organisasi dan Kesesuaian Tugas Pada Kinerja Karyawan. E-Jurnal Akuntansi Universitas Udayana Universitas Udayana, 17(3), 2225-2252.

Weyai, M. S. (2012). Kesesuaian Tugas-Teknologi dan Utilisasi Teknologi Informasi terhadap Kinerja Karyawan (Studi pada Pegawai Biro Universitas Cenderawasih Kota Jayapura). Tesis. Program Pasca Sarjana Universitas Kristen Satya Wacana Salatiga.

Zare, I. (2012). Study of effect of accounting information systems and softwares on qualitative features of accounting information. International Journal of Management Sciences and Business Research, 1(4), 1-12. 